\title{
THE RECENT EVOLUTION OF PENSION FUNDS IN THE NETHERLANDS: THE TREND TO HYBRID DB-DC PLANS AND BEYOND
}

\author{
Eduard H.M. Ponds and Bart van Riel*
}

CRR WP 2007-9

Released: April 2007

Draft Submitted: March 2007

\author{
Center for Retirement Research at Boston College \\ Hovey House \\ 140 Commonwealth Avenue \\ Chestnut Hill, MA 02467 \\ Tel: 617-552-1762 Fax: 617-552-0191 \\ http://www.bc.edu/crr
}

* Eduard H.M. Ponds is Head of Strategy in the Finance Department of the ABP Pension Fund and an affiliated researcher at Netspar. Bart van Riel is a senior policy officer at the Netherlands Social-Economic Council (SER) and a researcher at Leiden University. This paper was prepared for the research department of the French Ministry of Employment, Social Cohesion and Housing and the French Ministry of Health Solidarities. The findings and conclusions are solely those of the authors and do not represent the views of the ABP Pension Fund, Netspar, SER, Leiden University, or Boston College.

(C) 2007, by Eduard H.M. Ponds and Bart van Riel. All rights reserved. Short sections of text, not to exceed two paragraphs, may be quoted without explicit permission provided that full credit, including $($ ) notice, is given to the source. 


\title{
About the Center for Retirement Research
}

The Center for Retirement Research at Boston College, part of a consortium that includes parallel centers at the University of Michigan and the National Bureau of Economic Research, was established in 1998 through a grant from the Social Security Administration. The Center's mission is to produce first-class research and forge a strong link between the academic community and decision makers in the public and private sectors around an issue of critical importance to the nation's future. To achieve this mission, the Center sponsors a wide variety of research projects, transmits new findings to a broad audience, trains new scholars, and broadens access to valuable data sources.

\author{
Center for Retirement Research at Boston College \\ Hovey House \\ 140 Commonwealth Avenue \\ Chestnut Hill, MA 02467 \\ phone: 617-552-1762 fax: 617-552-0191 \\ e-mail: crr@bc.edu \\ www.bc.edu/crr
}

\author{
Affiliated Institutions: \\ American Enterprise Institute \\ The Brookings Institution \\ Center for Strategic and International Studies \\ Massachusetts Institute of Technology \\ Syracuse University \\ Urban Institute
}




\begin{abstract}
According to the classification in official statistics, Dutch pension plans have mainly preserved their DB character in recent years. The dominant reaction of pension funds to the fall in funding ratios at the beginning of this century has been a switch from final-pay schemes to average-wage schemes. This contrasts sharply with the experience in the United States and the United Kingdom, where the fall in pension funding ratios has accelerated the switch from DB to DC schemes.
\end{abstract}

This paper scrutinizes the recent evolution of Dutch pension plans: how does the evolution of Dutch pension funds diverge from that of Anglo-Saxon pension funds, and how can we explain this divergence? Using an ALM framework, we argue that the current average-wage pension plans may be better viewed as hybrid DB-DC schemes, as indexation of all liabilities has been made solvency-contingent. Because these hybrid plans make use of two steering mechanisms to control solvency risk, Dutch pension funds display a high effectiveness in minimizing the risk of under-funding.

The current hybrid schemes reflect a compromise between the various stakeholders. We examine the institutional basis for this compromise, and contrast this with the situation in Anglo-Saxon pension funds, where primarily employers are responsible for absorbing funding deficits, which gives them in turn more grip on pension plan design issues. In addition, we look at the role of unions, the strong preferences within the Dutch society for collective risk-sharing, and the underlying high level of social trust, as explanations for the divergence with the experience in the US and the UK.

For the longer term, we foresee that Dutch pension plans will shift further towards stand-alone multimember plans, often being called collective DC. This will be accompanied by more differentiation in risk exposure between younger and older members.

Collective risk-sharing will thus remain an important element in Dutch pension funds. In this sense, the evolution of Dutch pension schemes diverges from the developments of Anglo-Saxon pension funds, where risks are shifted more to the individual. Finally, we argue that collective risk-sharing has some important advantages over individual risk-sharing. 


\section{Introduction}

As in most developed countries, the institutional structure of the pension system in the Netherlands is organized as a three-pillar system. The first comprises the public pension scheme, offering a basic flat-rate pension to all retirees. Financing is on a pay-as-you-go basis. The benefit level keeps pace with the legal minimum wage. The second pillar provides former workers an additional income from the supplementary scheme. The third comprises personal savings, which individuals undertake at their own expense.

The supplementary pension system in the Netherlands is organized mainly as a funded definedbenefit plan. The benefit entitlement is determined by years of service and a reference wage, which can be final pay or the average wage over the years of service. The defined-benefit formula takes into account the retirement benefit of the public scheme. In the postwar period, the plans primarily were structured as final-pay plans. Many pension funds aimed at a gross benefitincluding the public pension - of $70 \%$ of the gross wage income last earned. This maximum will usually be reached after 40 years of service, as the typical accrual rate is $1.75 \%$. As we explain in this paper, many pension funds have switched from final-pay plans to average-wage plans.

In an average-wage plan, individuals accrue pension rights yearly based on a percentage of the salary earned in each year of their working life (rather than the final year, as in a final-pay plan), usually re-valued upwards each year to take account of inflation or wage growth. The accrual rate is $2 \%$ or even higher, as for many individuals a total pension equal to $80 \%$ of average wage corresponds with $70 \%$ final pay. After retirement, benefits are mostly inflation-indexed or wageindexed. The indexation, however, is conditional on the financial position of the pension fund.

The law stipulates that pension promises made to employees must be funded. Furthermore, the assets for the defined benefits have to be held within a separate trust, usually organized as a pension fund. Three types of pension funds can be distinguished. The first type is the industry pension fund, which is organized for a specific branch of industry (construction, healthcare). The law stipulates that participation in an industry pension fund is mandatory for all firms operative in the branch. A company can opt out only if it establishes a company pension fund that offers a better pension plan to its employees than the pension plan of the industry fund. This is the second type of pension fund. When a supplementary scheme exists, either as a company pension fund or as an industry pension fund, participation by the workers is generally mandatory. This is governed by collective labor agreements. The third type pension fund is an occupational pension fund, which is organized for a specific group of professionals, like the medicine profession.

The Dutch pension-fund system is sizeable, and covers more than $90 \%$ of the labor force. As reported by table 1 , the value of assets under management at the end of 2005 was 637 billion euros, which is $125 \%$ of national income. More than 85 percent of all pension funds are company pension funds. The remaining 15 percent are predominantly industry pension funds, and there are a small number of occupational pension funds (e.g. medical doctors). 
The industry pension funds are the really big players in terms of the relative share in total active members and assets under management. There are 80 industry-wide pension funds, covering twothirds of all assets and almost 85 percent of all plan participants. Standing out among these are the civil servant pension fund APB (191 bln euros end of 2005) and PGGM, the pension fund for employees in the health sector (71 bln euros end of 2005). These two funds belong to the biggest pension funds in the world, and together they cover almost $30 \%$ of all active members and $40 \%$ of total assets under management. Approximately 700 company pension funds encompass $30 \%$ of the remaining assets and $15 \%$ of the plan participants. Occupational pension funds are mostly very small funds.

Table 1. Pension funds in the Netherlands (end of 2005)

\begin{tabular}{lccc} 
& $\begin{array}{c}\text { Number of } \\
\text { funds }\end{array}$ & Assets & $\begin{array}{c}\text { Active } \\
\text { participants }\end{array}$ \\
\hline Company pension funds & in \% & in \% & in \% \\
& 86 & 30.5 & 14.5 \\
Industry-wide & 12.5 & 66.7 & 84.8 \\
$\quad$ ABP (public servants and education) & & 29.8 & 18.5 \\
$\quad$ PGGM (health) & & 11.1 & 16.9 \\
& 1.5 & 2.8 & 0.7 \\
Occupational pension funds & $100 \%$ & $100 \%$ & $100 \%$ \\
Total & & & \\
& 822 & $637 \mathrm{bln} €$ & 623,3000 \\
Total (absolute numbers) & & &
\end{tabular}

At the beginning of this century, pension funds in the Netherlands, the US and the UK were hit by a perfect storm on equity markets (see Boeri et al. 2006: 13-14). As a result, the funding ratios fell sharply in these countries. In this paper we compare the way Dutch pension funds reacted to these events with the experiences in the UK and the US. How did the Dutch reaction diverge from the reaction in the two Anglo-Saxon countries, and what explains this divergence? We focus on the change in pension plans as a reaction to the funding crisis. At first sight, although more participants of Dutch pension schemes now have a DC-type plan (table 2), over 90 percent of active participants still have some form of DB plan, and the Dutch pension system seems therefore to have preserved its DB character. 
Table 2. Ordering of pension funds according to type of pension plan (percentage of active participants, 1998-2005)

\begin{tabular}{|c|c|c|c|c|c|c|}
\hline & DC plans & DB plans & & & & \\
\hline & Total & Total & Final pay & Average wage & Combination & Fixed amount \\
\hline 1998 & 0.8 & 99.2 & 66.5 & 25.0 & 6.0 & 1.7 \\
\hline 1999 & 1.4 & 98.6 & 59.6 & 31.2 & 6.2 & 1.6 \\
\hline 2000 & 3.1 & 96.9 & 58.7 & 30.6 & 6.2 & 1.4 \\
\hline 2001 & 3.9 & 96.1 & 56.1 & 32.2 & 6.5 & 1.3 \\
\hline 2002 & 6.1 & 93.9 & 54.3 & 31.6 & 6.8 & 1.1 \\
\hline 2003 & 5.8 & 94.2 & 49.3 & 35.4 & 8.6 & 0.9 \\
\hline 2004 & 5.7 & 94.3 & 12.0 & 72.6 & 8.6 & 1.0 \\
\hline 2005 & 6.1 & 93.9 & 10.6 & 74.3 & 8.1 & 0.9 \\
\hline $\begin{array}{r}\Delta 1998- \\
2005\end{array}$ & +5.3 & -5.3 & -55.9 & +49.7 & +2.1 & -0.8 \\
\hline
\end{tabular}

Source: DNB

As table 2 clarifies, the predominant switch after 2001 was not from DB to DC, but from DBfinal salary to DB-average salary. This contrasts sharply with the experience in the US and the UK, where the perfect storm accelerated the switch from DB to DC (Munnell 2006). In 2004, DC-plan assets amounted to 22 percent of total occupational plan assets in the UK and to 35 percent in the US. The corresponding figure in the Netherlands is 9 percent (OECD 2006).

This paper is structured as follows. Section 2 provides some background information about the immediate causes for the recent evolution of Dutch pension funds: the fall in funding ratios, the switch to fair-value accounting and the imposition of the new regulatory framework by the supervisor (De Nederlandsche Bank). Section 3 takes a closer look at the nature of the switch within the Dutch pension funds; we try to ascertain to what extent pension funds have maintained their DB-character and in what ways they deviate, in this respect, from developments in the UK and the US. The aim of the fourth section is to explain why Dutch pension funds did not switch into outright DC schemes. Section 5, which speculates on how robust recent changes in Dutch pension funds are, also puts into perspective recent and future changes in the Dutch occupational pension system. Section 6 concludes.

\section{Background: The fall in funding ratios and the need to act}

\subsection{The fall in funding ratios}

Pension funds in the Netherlands experienced a serious fall in funding ratios after the millennium turn (table 3). The funding ratio is defined as assets under management over the value of pensionfund liabilities. The fall in funding ratios was due, in particular, to two developments in financial markets. The first was the collapse of stock markets, and therefore the decline of the value of assets held by pension funds; the second involves the fall in interest rates, which approached historic low levels and which led to a sharp increase in the fair value of pension-fund liabilities. 
Table 3. Average funding ratio Dutch pension funds (2000-2005)

\begin{tabular}{lcccccc}
\hline Average funding ratio (nominal) & 2000 & 2001 & 2002 & 2003 & 2004 & 2005 \\
\hline All funds & 132 & 118 & 101 & 104 & 119 & 125 \\
Company funds & 135 & 123 & 110 & 117 & 123 & 130 \\
Industry-wide funds & 131 & 116 & 97 & 99 & 118 & 123 \\
\hline
\end{tabular}

Source: DNB

\subsection{Fair-value accounting}

Also in the years after the millennium turn, fair-value principles entered pension-fund accounting, following the worldwide introduction of new international accounting rules. The fall in funding ratios could no longer be masked, since pension funds are now required to report assets and liabilities on a fair-value base (see Boeri et al. 2006: 66-67).

The fair-value accounting principles replaced the traditional actuarial approach, which typically was grounded on rules-of-thumb regarding valuation and accounting issues. The main goal of this approach was to arrive at stability in the contribution rate and the funding ratio over time. This came at the price of suppressing the risk exposure in the funding process. Actually, the actuarial approach implied a self-constructed representation of the solvency position of a pension fund without any link to financial markets. The fair-value approach relies on methods of financial theory and techniques prevailing in financial markets. The main goal is to make an objective analysis of the solvency position of the pension fund and of the implied risks in meeting the promised benefits.

The fair-valuation principles inevitably lead to high volatility in the value of pension-fund assets and liabilities. Thus, liabilities have become more volatile, since the actuarially fixed discount rate was replaced by the actual yield curve of interest rates prevailing in the market. The transition to fair-value methods has forced pension funds to redefine their risk management (Kortleve et al. 2006). Since the explicit measurement of risk exposure reveals the high volatility in the solvency position, the reported probability of under-funding increases considerably, compared to the actuarial approach. One way or another, fair-value accounting will lead to higher funding costs of pensions. Pension funds have to choose either less risk taking or a higher solvency reserve position. As we will see further, adjusting the pension promise has become a fruitful way out.

\subsection{Policy choices and requirements imposed by the supervisor}

Supervision of pension funds in the post-war period was quite loose. The solvency requirements never affected pension funds - not even during the seventies, when pension funds actually were in a situation of severe underfunding. Actually, there were no explicitly documented requirements at all. The perception by pension funds was that the funding ratio based on the fixed $4 \%$ discount rate for liabilities had to be at least $100 \%$. 
The period of supervisory tolerance came to an abrupt end in September 2002. Faced by the solvency crisis, the supervisor imposed strict requirements on pension funds in order to restore the fall in funding ratios in a short period of time and to raise contribution levels to reflect the true costs of pensions (details in Box 1, below). Meeting these requirements would necessitate either a steep increase in contributions or severe cuts in benefits - or a combination of the two. A storm of critique arose. High contributions would harm the macro-economy (van Vuren 2003). Furthermore, high contribution rates would undermine support for the defined-benefit plans and might force an undesirable shift to individual defined-contribution plans. The debate resulted in a relaxation of the requirements. Also consensus grew to renew pension-fund supervision. As of January 2007, the Financial Assessment Framework is in operation, which defines solvency requirements in a stochastic fair-value framework (see Box 1). The new requirements have compelled pension funds to improve their risk management tools in order to have better control over their short-term solvency position and to ensure that the promised benefits can be met in the long run with adequate certainty, given the funding policy (contributions and asset mix).

\section{Box 1: The 2002 circulation letter of the pension supervisor}

On September 30, 2002, the supervisor at that time (the Pensions and Insurance Supervisory Authority (PVK), currently part of De Nederlandsche Bank) circulated a letter to all pension funds, clarifying the current financial supervisory framework and outlining the adjustments needed to restore pension-fund solvency and establish more prudent financial management in the short- and medium run (see OECD 2004: 58). The letter contained three main elements:

- Pension funds with a funding ratio below 105 percent had to restore this within one year. In 2002, 10 percent of pension funds had a funding ratio below 100 percent, among them a number of large pension funds. More than 30 percent of pension funds had a funding ratio between 100 and 110 percent. The new pension law that came into force as of January 2007 extended the one-year recovery period to three years.

- Pension funds with a funding ratio below 130 percent were asked to present a plan that should indicate by which means they intend to raise their funding ratio at least to 130 percent within a maximal period of eight years. This concerned more than 70 percent of all pension funds. In the new Principles on the Regulation of Financial Regulation of Pension Funds, which were approved by Parliament in March 2004, the time horizon of eight years was extended to 15 years.

- Pension funds had to raise contribution rates to levels that would, at the least, cover costs. The subsequent discussion focused primarily how to valuate soft liabilities (for example, through solvency-contingent indexation). 


\subsection{Pension funds react: Raising contribution rates and changing pension plans}

This section briefly describes the way in which pension funds reacted to the funding crisis and the requirements imposed by the regulator to restore solvability. The focus is on the development of pension contributions, the change in pensions plans and the change in indexation. At the beginning of this century, approximately 950 pension funds were operating in the Netherlands, and not all have reacted in a similar way. Since the main focus here is on the general evolution of Dutch pension funds, we review the dominant trends regarding company pension funds and industry-wide pension funds. For a more detailed analysis on the differential responses by Dutch funds, see Kakes (2006). As shown in table 3, sector-wide pension funds were hit harder by the perfect storm than company funds were. A possible explanation for this is that larger funds invested more in (foreign) equity and that larger funds are predominantly industry pension funds. At least one-third of the shift in the 1990s in the investment portfolio of pension funds towards foreign equity (see table 1) can be explained by the change in investment strategy of the biggest pension fund, APB (Van Riel, Hemerijck and Visser 2003; pp. 70-71).

\section{Development of contributions}

Table 4 shows that contributions more than doubled between 2000 and 2005 - almost $13 \%$ of wages. In relation to gross wages, contributions were raised by around $100 \%$ during this period. The relative increase in contributions of company funds and industry funds was similar. Company funds, however, increased contributions much faster. An industry pension fund needs more time to reformulate funding policy, as representatives of employers and employees both have to agree (see DNB 2005; Kakes 2006).

Table 4. Contributions paid to Dutch pension funds (millions of euros)

\begin{tabular}{lcccccc}
\hline & 2001 & 2002 & 2003 & 2004 & 2005 & $\begin{array}{c}\Delta \% \\
2001-5\end{array}$ \\
\hline a. Contributions (bln) & & & & & 96 \\
b. Gross wage sum (bln) & 182.8 & 18.5 & 20.9 & 22.9 & 25.2 & 86 \\
c. Contribution rate (a/b) & $7.0 \%$ & $9.8 \%$ & $10.8 \%$ & $11.8 \%$ & $12.8 \%$ & 83 \\
d. Contributions company & 3.6 & 7.5 & 7.0 & 6.8 & 7.3 & 103 \\
funds (bln) & & & & & 196.6 & 95 \\
e. Contributions industry funds & 9.0 & 10.8 & 13.6 & 15.8 & 17.6 & \\
(bln) & & & & & & \\
\hline
\end{tabular}

Source: DNB (rows a,d,e); Statistics Netherlands (row b)

Change in pension plans

The developments of pension plans for all pension funds appear in table 2. Table 5 compares the shift in pension plans between company - and industry funds. 
Table 5. Relative shares of DB and DC plans in total active membership in Dutch pension plans

\begin{tabular}{c|ccccc|}
\hline & DC & DB & & & \\
\hline Company & & Total & Final wage & Average wage & Combination \\
1998 & 2.4 & 97.6 & 56.5 & 19.1 & 21.6 \\
2005 & 8.5 & 91.5 & 19.5 & 38.5 & 33.2 \\
$\Delta$ 1998-2005 & +6.1 & -6.1 & -37.0 & +19.5 & +11.6 \\
Industry* & & & & & \\
1998 & 0.3 & 99.7 & 70.5 & 27.9 & 0.0 \\
2005 & 2.7 & 97.3 & 9.2 & 84.6 & 3.2 \\
$\Delta$ 1998-2005 & +2.4 & -2.4 & -61.3 & +56.7 & +3.2 \\
\hline
\end{tabular}

Source: DNB; * Mandatory industry funds

Two conclusions can be drawn from this comparison:

1. The switch away from final-salary schemes has been more pronounced in industry funds. In 1998, 70 percent of active participants had a final salary pension plan. In 2005, this number had fallen to 9 percent. The corresponding figures for company funds are 56 percent and 19 percent. Particularly decisive regarding the developments in industry funds was the switch of both of the largest pension funds, ABP and PGGM, to average salary schemes in 2004.

2. Industry funds have almost exclusively switched from final-wage plans to average-wage plans. The switch to combination plans or DC plans has been small. In contrast, company funds have switched more to combination plans and DC plans. Combination plans are grouped in this table as DB plans. However, a typical combination plan in company funds combines a DB-type plan up to a certain ceiling, and a DC-type plan for the remainder of the salary. Consequently, table 5 probably underreports the shift to DC-type plans in company funds.

\section{Indexation}

After the perfect storm, pension funds tried to recover from their low funding ratios. The recovery came partly from indexation cuts. One may speak of an indexation cut when a given level of indexation is less than full indexation - the latter usually tied to price inflation or wage growth. Table 6 shows, that in the years 2004 and 2005 the given indexation level lagged behind price inflation.

Table 6. Indexation in a sample of Dutch pension plans (2004-2005)

\begin{tabular}{|c|c|cc|}
\hline & $\begin{array}{c}\text { Price } \\
\text { Inflation }\end{array}$ & \multicolumn{2}{|c|}{$\begin{array}{c}\text { Indexation benefits and accrued } \\
\text { liabilities* }\end{array}$} \\
\hline & & Company & Industry \\
2004 & 2.0 & 1.6 & 1.6 \\
2005 & 1.2 & 0.9 & 0.2 \\
\hline
\end{tabular}

Source: DNB

*The sample consists of the 24 largest pension funds in the Netherlands; approximately half of these have limited indexation below inflation. The data shown in the table report the weighted-average indexation. 


\section{Pension-plan redesign by Dutch pension funds and risk reallocation}

\subsection{Introduction}

As a result of the switch from final-pay to average-wage-type entitlements, almost three-quarters of participants in Dutch pension funds now have an average-wage entitlement. Official statistics classify these funds as DB schemes. However, a typical characteristic of the Dutch average-salary schemes is that indexation of all accrued liabilities is made dependent on the solvency position of the pension fund through a so-called policy ladder. A policy ladder enlarges the funds' riskbearing capacity, and is part of the pension deal agreed upon by the social partners within the board of trustees. A typical policy ladder relates the contribution policy and indexation policies explicitly one-to-one to the financial position of the pension fund. This section evaluates some examples of policy ladders and elaborates on the consequences of the redesign of pension plans, questioning whether current average-wage plans can still be characterized as genuine DB schemes.

\subsection{The hybrid character of current Dutch pension funds}

Diagram 1 shows the functioning of a policy ladder for a typical pension plan currently in the Netherlands. In this diagram, the x-axis denotes the value of the assets $A$ of the pension fund under study. A pension fund is said to be fully funded when assets $A$ equal the value of the real liabilities $L_{R}$, the latter being the value of accrued rights when full indexation always would be given. $L_{R}$ is calculated by discounting the accrued rights with the real yield curve net of real wage growth (compare also Box 2). The value of the nominal liabilities, $L_{N}$, is the value of accrued rights when no indexation would be given. The size of $L_{N}$ is determined by discounting the accrued liabilities with the nominal yield curve. The difference between real and nominal liabilities, $L_{R}-L_{N}$, is the required indexation reserve that is needed to cover the indexation promise to the participants. The actual indexation reserve position is $A-L_{N}$, which may be either positive or negative. Along the vertical axis, the contribution rate and the indexation rate are set.

\section{Box 2 Valuation of accrued pension rights}

Plan members accrue pension rights during their years of service. The aggregate accrued pension rights in the pension fund will give rise to a yearly stream of benefits from now to some 80 years in the future. The present value of this stream of foreseeable benefits $B_{1}, B_{2}, \ldots, B_{80}$ is the value of the liabilities of the pension fund, where $B_{1}$ is the benefit cash flow in period $1, B_{2}$ in period $t=2$ and so on.

The pension plan in operation usually specifies some rules regarding indexation. Indexation rules stipulate in what way the stream of foreseeable benefits has to be increased with the inflation or wage growth from year to year. A plan may define that there is no indexation at all. The benefits are fixed in nominal terms, and can be increased only by an additional year of service. Expression [1] shows how the nominal value of liabilities $L_{N}$ can be determined by discounting future benefits with the nominal rate of interest, where $r_{N}$ reflects the (constant) nominal rate of interest: 
[1] $\quad \mathrm{L}_{\mathrm{N}}=\frac{\mathrm{B}_{1}}{1+\mathrm{r}_{\mathrm{N}}}+\frac{\mathrm{B}_{2}}{\left(1+\mathrm{r}_{\mathrm{N}}\right)^{2}}+\ldots+\frac{\mathrm{B}_{80}}{\left(1+\mathrm{r}_{\mathrm{N}}\right)^{80}}=\sum_{\mathrm{t}=1} \frac{\mathrm{B}_{\mathrm{t}}}{\left(1+\mathrm{r}_{\mathrm{N}}\right)^{\mathrm{t}}}$

A pension plan may also have prescribed that accrued rights are adjusted yearly for price inflation or wage growth. The real value of liabilities $\mathrm{L}_{\mathrm{R}}$ is then the present value of the stream of indexed benefits. Expression [2] reflects the value of price-indexed liabilities, where $\pi^{\mathrm{e}}$ reflects the (constant) expected indexation. Expression [2] can be rewritten as [2a] by splitting the nominal rate of interest into its two base components: the real rate of interest, $r_{R}$, and the expected inflation rate, $\pi^{\mathrm{e}}:\left(1+\mathrm{r}_{\mathrm{N}}\right)=\left(1+\mathrm{r}_{\mathrm{R}}\right)\left(1+\pi^{\mathrm{e}}\right)$.

$$
\text { [2a] } \quad \mathrm{L}_{\mathrm{R}}=\frac{\mathrm{B}_{1}}{\left(1+\mathrm{r}_{\mathrm{R}}\right)}+\frac{\mathrm{B}_{2}}{\left(1+\mathrm{r}_{\mathrm{R}}\right)^{2}}+\ldots+\frac{\mathrm{B}_{80}}{\left(1+\mathrm{r}_{\mathrm{R}}\right)^{80}}=\sum_{\mathrm{t}=1} \frac{\mathrm{B}_{\mathrm{t}}}{\left(1+\mathrm{r}_{\mathrm{R}}\right)^{\mathrm{t}}}
$$

Expression [3] specifies the value of wage-indexed liabilities, where the term y reflects real wage growth.

[3] $\quad L_{R}=\frac{B_{1}}{\left(1+r_{R}-y\right)}+\frac{B_{2}}{\left(1+r_{R}-y\right)^{2}}+\ldots+\frac{B_{80}}{\left(1+r_{R}-y\right)^{80}}=\sum_{t=1} \frac{B_{t}}{\left(1+r_{R}-y\right)^{t}}$

The base contribution rate is fixed. There is room for full indexation equal to the wage growth when the value of assets is equal to or larger than the value of the real liabilities: $\mathrm{A} \geq L_{R}$. Then, the actual indexation reserve $\mathrm{A}-L_{N}$ is at least equal to the required indexation reserve $L_{R}-L_{N}$. The indexation rate will be zero when the assets are equal to or even below the nominal liabilities: $\mathrm{A} \leq L_{N}$. The actual indexation reserve then is zero - or is even negative. Between these two points (i.e. when $L_{N}<\mathrm{A}<L_{R}$ ), indexation follows the wage growth partly where the indexation given is determined by the proportion of the actual indexation reserve in relation to the required indexation reserve. When $\mathrm{A}>L_{R}$, catch-up indexation may be given up to a maximum equal to the previously missed indexation due to indexation cuts. The possibility of catch-up indexation is indicated by the dotted line. 


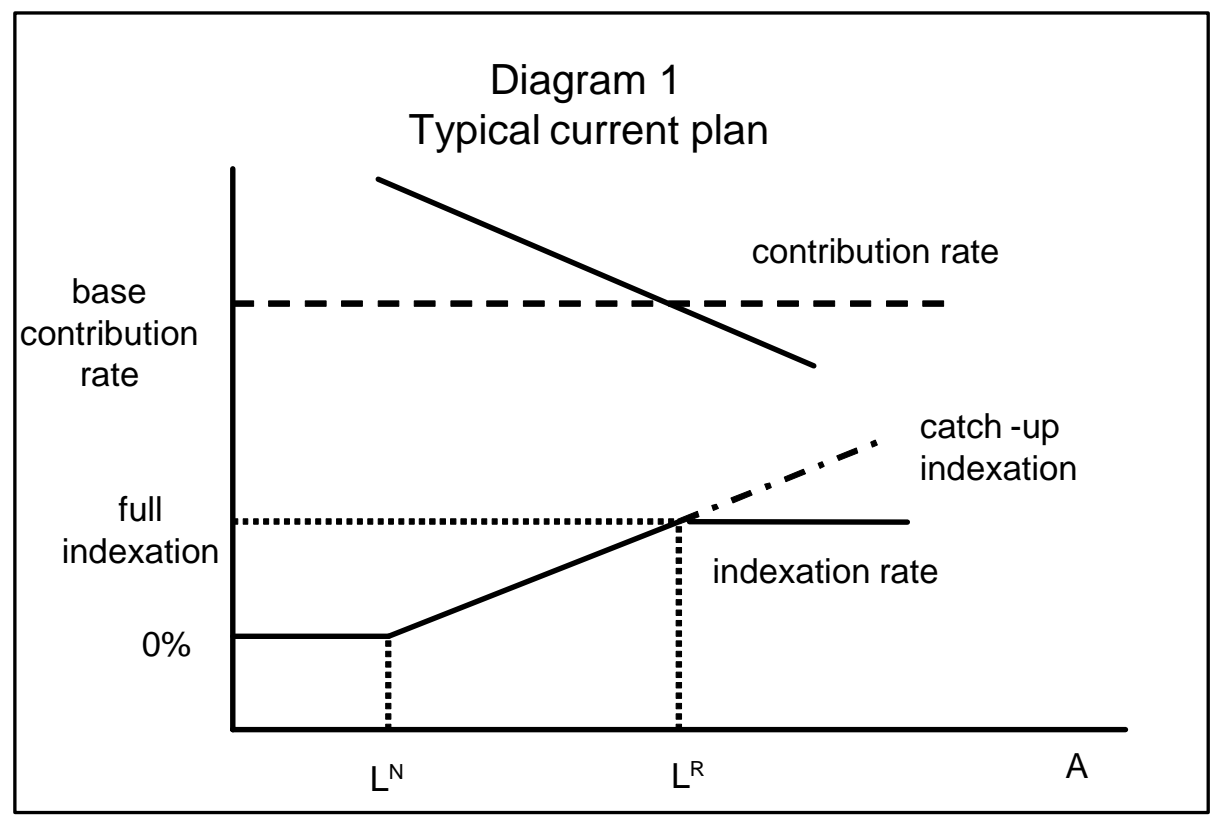

The broadening of solvency-contingent indexation implies that the final pension result will be partly dependent on investment returns. The current typical average wage scheme can therefore better be described as a hybrid DB-DC plan, keeping a midway position between a traditional DB plan, with flexible contributions and well-defined indexed pensions, and a DC plan, with uncertainty as to the final pension result because of uncertainty on the rate of return on investments. The hybrid plan is partly DB by nature because the yearly accrual of pension rights is specified in the same way as a traditional DB plan, and because contributions are flexible, depending on the financial position of the pension fund. The hybrid plan is partly DC by nature, as the yearly indexation is related to the financial position of the fund and therefore is related to the investment returns.

A number of pension funds have gone one step further than the hybrid plan by abolishing the use of the contribution rate as a risk-steering instrument. This type of plan can be characterized as a collective DC plan with fixed contributions but flexible benefits, depending on the financial situation of the pension fund.

\subsection{A further examination of the hybrid character of Dutch pension funds}

In order to determine more specifically the hybrid character of Dutch pension funds and the consequences of the shift to hybrid schemes, we use an ALM framework to compare the allocation of risk among the plan members in a typical current pension plan to both a traditional DB plan and collective DC plan. 


\section{Box 3: Asset Liability Management (ALM)}

Pension funds use ALM analysis to evaluate the pension deal in operation and to explore the performance of alternative pension deals. A pension deal defines, essentially, what is being promised, how the promises are funded (asset mix and contribution policy) and who is bearing the risks in the funding process (riskallocation rules). ALM is broadly seen as a cornerstone for the fund policy, as it provides insight into the realism and the sustainability of the pension deal in operation at different horizons. Typically, an ALM study uses an economic model to produce stochastic simulations of returns on asset classes and other relevant economic data, such as inflation. A scenario analysis is subsequently performed that results in probability distributions for the key variables. Sensitivity analysis is usually carried out to explore specific policy variants in asset mix, contribution policy and indexation rules. Policy variants are evaluated in terms of expected values and relevant risk measures for key variables - the funding ratio, the contribution rate, the indexation rate, and so on. Moreover, one can easily take care of specific constraints, such as the funding requirements of the supervisor (e.g. a minimum probability of under-funding) and a maximum level of contribution rate.

Diagram 2 is a stylized representation of risk allocation within a traditional DB plan structure wherein indexed benefits are guaranteed and funding risks are absorbed by flexible contributions. This can be seen as a stylized representation of risk bearing in the Netherlands in the postwar period up to 2000. As in diagram 1, the base contribution rate is fixed. Additional contributions are not necessary when assets match real liabilities: $A=L_{R}$. A situation of real under-funding, $A$ $<L_{R}$, or real over-funding, $A>L_{R}$, leads to, respectively, a surcharge to, or a cut in, the contribution rate. A situation of under-funding or over-funding is smoothed out over a period of 35 years.

The setting of solvency-contingent indexation in the collective DC plan in diagram 3 is the same as in the hybrid DB-DC plan (diagram 1). However, the contribution rate in the collective DC plan is fixed. This plan also allows for catch-up indexation like the hybrid plan does, once again indicated by the dotted line. 

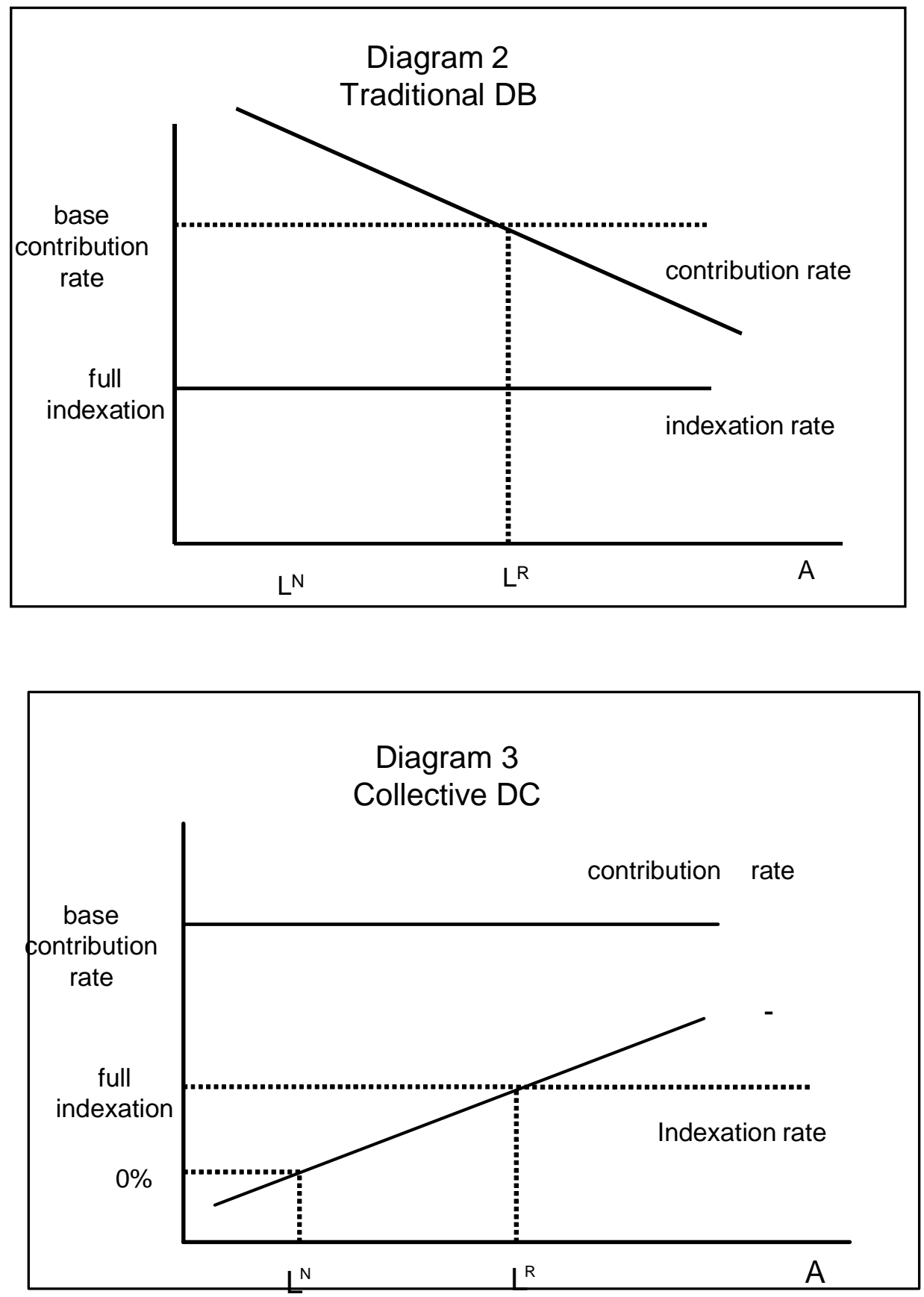

We evaluate the performance of the three examples of policy ladders described in diagrams 1-3. Results are derived from Hoevenaars \& Ponds (2006). The pension fund under study is a stylized pension fund as a representative for industry-wide pension funds in the Netherlands. A classic ALM study is applied for a horizon of 20 years (2006-2025). For each of the three variants, the asset mix is composed of 50\% stocks and 50\% bonds. Table 7 presents means and risks of the 
key variables. On average, the expected return on a $50-50$ mix over the 5000 scenarios is $6.7 \%$. The average growth rate of liabilities is $4.5 \%$, consisting of the indexation component (equal to the average wage growth of $2 \%$ ) and the discount-rate component (equal to $2.5 \%$ ). On average, therefore, the excess return of assets over the liability growth rate is $2.2 \%$.

Table 7. ALM projections

\begin{tabular}{lcc}
\hline & Mean & $\begin{array}{c}\text { Risk } \\
\text { (standard deviation) }\end{array}$ \\
\hline Stocks & 9.0 & 22.0 \\
Rate of interest & 4.5 & 1.0 \\
Wage growth & 2.0 & 1.0 \\
Inflation & 2.0 & 1.0 \\
Discount rate real liabilities & 2.5 & 1.0 \\
Excess return & 2.2 & 9.5 \\
\hline
\end{tabular}

We set the initial real funding ratio at $85 \%{ }^{1}$, reflecting the current situation of underfunding at many pension plans in the Netherlands.

Table 8 summarizes the classic ALM results for the three variants of plan design. The text below the table explains the significance of the indicators. The reported evidence in this table provides insights regarding the question of how pension-plan design (i.e. the structuring of the policy ladder) determines the way in which the risks in the funding process are absorbed - by adjustments in contributions or by adjustments in indexation rate or in funding ratio.

\footnotetext{
${ }^{1}$ For the stylized pension fund, this implies a nominal funding ratio of $120 \%$. A nominal funding ratio of about $140 \%$ corresponds with a real funding ratio of $100 \%$.
} 


\begin{tabular}{|c|c|c|c|c|}
\hline & & $\begin{array}{c}\text { Traditional } \\
\text { DB }\end{array}$ & $\begin{array}{l}\text { Current hybrid } \\
\text { DB-DC plan }\end{array}$ & $\begin{array}{l}\text { Collective } \\
\text { DC }\end{array}$ \\
\hline & & diagram 2 & diagram 1 & diagram 3 \\
\hline Real Funding ratio & & & & \\
\hline Mean & 2025 & $106 \%$ & $106 \%$ & $105 \%$ \\
\hline Median & 2025 & $106 \%$ & $122 \%$ & $110 \%$ \\
\hline Standard deviation & 2025 & $19 \%$ & $16 \%$ & $22 \%$ \\
\hline mismatch risk & av $20 \mathrm{yr}$ & $9 \%$ & $8 \%$ & $8 \%$ \\
\hline within $\mathrm{P}(\mathrm{A}<\mathrm{Ln})$ & 2025 & $11 \%$ & $2 \%$ & $5 \%$ \\
\hline Contribution rate & & & & \\
\hline Mean & av $20 \mathrm{yr}$ & $18 \%$ & $18 \%$ & $17 \%$ \\
\hline Jump per year & av $20 \mathrm{yr}$ & $3.3 \%$ & $2.6 \%$ & $0 \%$ \\
\hline Indexation ratio & & & & \\
\hline Mean & av $20 \mathrm{yr}$ & $100 \%$ & $93 \%$ & $91 \%$ \\
\hline Median & av $20 \mathrm{yr}$ & $100 \%$ & $83 \%$ & $79 \%$ \\
\hline $\mathrm{P}(\mathrm{IR}<100 \%)$ & av $20 \mathrm{yr}$ & $0 \%$ & $53 \%$ & $56 \%$ \\
\hline $\mathrm{P}(\mathrm{IR}$ cum $<90 \%)$ & 2025 & $0 \%$ & $16 \%$ & $23 \%$ \\
\hline $\mathrm{P}(\mathrm{IR}$ cum $<80 \%)$ & 2025 & $0 \%$ & $9 \%$ & $15 \%$ \\
\hline
\end{tabular}

Explanation Indicators table 8

The median, mean, and standard deviation of the real funding ratio are reported at the end of the 20-year evaluation period. Mismatch risk, defined as the degree of mismatch between the payoff structures of asset mix and liabilities, is measured by the standard deviation of the growth rate of the funding ratio. within $\mathrm{P}(\mathrm{A}<\mathrm{Ln})$ is the within probability of nominal under-funding; this is the probability of reaching a position of nominal under-funding within the 20 -year evaluation period. The third group of indicators relates to indexation quality. The median, mean, and standard deviation of the indexation ratio during the period of 20 years are shown. The yearly indexation ratio is measured as actual indexation over wage growth. The term $\mathrm{P}(\mathrm{IR}<100)$ indicates the frequency of less than full indexation. We also provide an indicator of the indexation quality cumulative over the entire 20-year period, the probability that the cumulative value of the indexation ratio at the end of the 20 -year period is less than $90 \%$ (less than $80 \%$, respectively) of cumulative end value of full indexation. 
The expected real funding ratio after 20 years in all three variants is improved strongly from the low level of $85 \%$ in 2006 , as shown by the mean and the median at the end of the evaluation horizon, which reach values above 100\%. The mismatch risk for a 50-50 mix for the three variants is slightly higher than $8 \%$. The variants differ in how this mismatch risk is absorbed. The traditional DB variant absorbs mismatch risk by adjusting the contribution rate in order to restore a situation of under-funding or over funding. This results in a high volatility of the contribution rate. The average year-to-year change in the contribution rate is $3.3 \%$-percentage points. The funding ratio risk and probability of under-funding are reduced strongly, due to the flexible contribution rate.

The hybrid plan makes use of two steering instruments to control solvency risk: adjustments in contributions and indexation. As a result, the within probability of under-funding almost vanishes. The collective DC variant has fixed contribution but flexible indexation. The within probability of under-funding slightly increases vis-à-vis the hybrid plan, reflecting the fact that the contributions are no longer part of the risk-bearing process. This also explains that the results on the indexation ratio are less good compared with the hybrid plan, as the indexation instrument has to take up more risk.

Changes in the policy setup of a pension fund may easily lead to redistribution of value and risk among the members. Hoevenaars \& Ponds (2006) also make use of a tool (so-called value-based generational accounting) to calculate value transfers among plan members due to policy changes. Figure 1 shows redistribution among plan members due to a switch from the traditional DB plan to a hybrid DB-DC plan, respectively, from the traditional DB plan to a collective DC plan. The horizontal axis denotes the age of the cohorts in the plan in 2006. We look 20 years forward, so also members of cohort -2 will be part of the labor force in 2025. The cohort with an age of 105 will die with certainty within one year. The vertical axis reports the change in generational accounts of each of the age cohorts (generations).

A key characteristic of a pension fund is that it can be seen as a zero-sum game. The total value to be distributed within the pension fund at a specific point in time is given, and is equal to the value of assets under management. The content of the pension deal is decisive with regard to how the total value is distributed among members.

Figure 1 shows that the step from the traditional DB plan to either the hybrid DB-DC plan or the collective DC plan leads to redistribution from old to young. The elderly members lose value, as they have to accept that de facto unconditional indexation policy is replaced by flexible benefits, depending on the financial soundness of the fund. The younger members win, since part of the risk bearing and funding burden can be shared with the elderly members. 


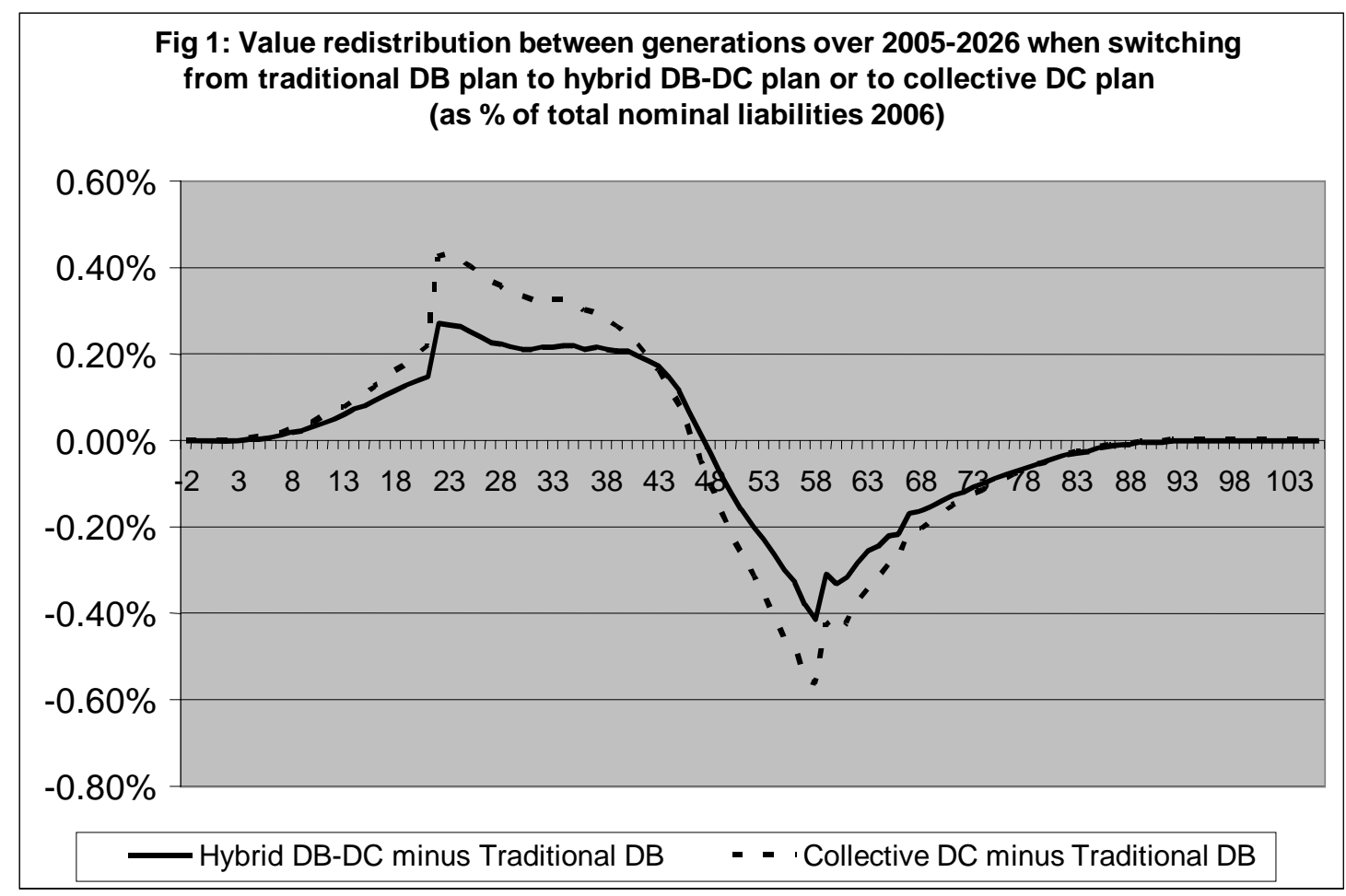

\subsection{Evaluation}

Pension-plan design is decisive with regard to how risk taken by the pension fund is allocated among stakeholders. Table 9 summarizes for key risk measures the performance of the three variants under study here. The key risk measures are as follows: the average annual change of the contribution rate (column 1), the cumulative deviation from full indexation (column 2) and the probability of nominal under-funding (column 3 ). The asset mix is the same for the three variants, so total risk to be distributed is the same for the three variants. The variants differ in the way in which risk is allocated over the stakeholders.

Table 9. Summary results of ALM analysis*

\begin{tabular}{lccc}
\hline & $\begin{array}{c}\text { Average annual } \\
\text { change of the } \\
\text { contribution rate over } \\
2006-2025\end{array}$ & $\begin{array}{c}\text { Probability cumulative } \\
\text { indexation is less than } 80 \% \text { of } \\
\text { cumulative full indexation at } \\
\text { the end of 2025 }\end{array}$ & $\begin{array}{c}\text { Probability of nominal } \\
\text { under-funding at the end of } \\
2025\end{array}$ \\
\hline Traditional DB & $\mathbf{3 . 2}$ & 0 & $\mathbf{1 1}$ \\
Collective DC & 0 & $\mathbf{1 5}$ & 5 \\
Current hybrid plan & 2.6 & 9 & 2 \\
\hline
\end{tabular}

*) See table 8 for explanations. Bold figures indicate the highest risk.

The table shows the various trade-offs confronted in pension-plan design. Full indexation in the traditional DB plan comes at the cost of both a higher risk of nominal under-funding and a high 
volatility of contribution rates. Fixed contribution rates in collective DC plans come mainly at the cost of high indexation risk. The current hybrid plan takes a midway position in these trade-offs: there is still volatility in contribution rates and there is less-than-full indexation, which leads to a considerable redistribution of value from older members to younger members. What is gained in the current plans is a lower probability of nominal under-funding in comparison to both traditional DB plans and collective DC plans. The pension funds introduced flexible indexations as the primary method to enhance solvency risk management.

\section{Explaining the switch in Dutch pension funds}

\subsection{Introduction}

The current hybrid DB/DC pension-plan structure uses adjustments in both contributions and indexation as steering instruments to control solvency risk. Section 4.2 attempts to explain why pensions plans rely on both instruments and not on one of the instruments exclusively. This seems to be a reflection of a compromise between the various stakeholders. Section 4.3, which looks at the institutional basis for this compromise, contrasts the Dutch experience with that of the UK and US, where employers were the dominant agents in the switch from DB to individual DC plans. We discuss why employers in the Netherlands were less able to control the evolution of pension funds and why they had to compromise. In this perspective, the governance structure and the need to compromise in the Dutch situation are central in explaining the evolution of pension funds.

\subsection{Average-wage plans as a compromise solution}

Traditionally, risk management by Dutch pension funds in the postwar period was done primarily by adjustments in the contribution rate. A high funding ratio gives rise to contribution cuts, whereas a funding ratio that is perceived as too low leads to an increase in the contribution rate. Given the tight deadlines set by the pension supervisor to restore solvency, and the requirement for cost-covering contribution rates, it is hardly surprising that the traditional instrument of raising contribution rates was no longer useful to restore solvency. Below we explain why risk management solely through the contribution rate was no longer appropriate. We then explain the switch from final-pay plans to average-wage plans from the need to extend solvency-contingent indexation from pension benefits to all accrued rights.

\section{Constraints on higher contribution rates}

After the millennium turn, awareness grew that risk management through contribution rates exclusively was no longer appropriate. First, since most Dutch pension funds stem from the 50s and $60 \mathrm{~s}$, they have now, after 40 years, a high degree of maturity — as a large group of members has reached the retirement age. Typical for a mature pension fund is that the ratio of pensioners over workers is high, and also that the ratio of the value of pension-fund liabilities over wages is high. The ratio between liabilities and total wages is expected to rise from approximately 2.5 now 
to 4.5 in 2030 . This sharp increase will severely undermine the effectiveness of the contribution rate as a steering instrument. To improve the funding ratio by $1 \%$ would require an additional contribution of $4.5 \%$ in the future, instead of the $2.5 \%$ in the present.

For employers, it was important to address this declining effectiveness of the contribution rate as a steering mechanism, and to spread risks more evenly over participants and sponsors. But this also was a concern for unions. Unions in the Netherlands have to strike an internal compromise between the interests of younger workers, on the one hand, and the interests of older workers and pensioners (who often retain their trade union membership), on the other. In most cases, moreover, union representatives in pension boards are often closely involved in wage negotiations. This explains why unions have been willing to spread risks more broadly between active members and pensioners. An exclusive reliance on contribution rates to absorb risks would run the risk of alienation of younger workers and put a heavy burden on wage negotiations, as employers would try to shift pension costs to workers.

\section{Constraints on lowering indexation of benefits}

In most final-wage pension plans, indexation of pension benefits was, at least on paper, dependent on the solvency position of the pension fund. Thus, in principle, pension funds could have invoked this possibility and shifted investment risk to pensioners. Given the maturity of most funds, this would have presented an effective instrument for restoring solvency. This would have been difficult, however, as the conditional indexation of pension benefits had been poorly communicated to participants. Moreover, the clauses had been seldom invoked, as the financial situation of most funds was healthy or it was considered to be so in view of the old actuarial framework for valuing pension liabilities. As a consequence, strong resistance from pensioners might have been expected. Pensioners might have felt that they were the victim of contribution holidays in the roaring 1990s, when they threatened to go to court in case pension funds decided to shift risk their way only. As many pensioners remain union members after retiring, unions could not neglect their concerns. A way out was to broaden solvency-contingent indexation to all liabilities - including accrued rights of active members. Technically, this implied a switch from final-wage plans to solvency-contingent average-wage plans.

\subsection{Adherence to collective risk-sharing: Explaining differences with the UK and the US}

Pension funds in the Netherlands are independent financial institutions governed by a board where both employers and unions are represented. The influence of employers in the AngloSaxon pension funds is much bigger, in contrast; they are - as sponsors of pensions funds responsible for correcting situations of under-funding. This difference in the government and regulation of pension funds goes a long way toward explaining why in the US and the UK there has been a stronger shift to individual DC schemes (where employers have shifted risks to their employees), while in the Netherlands risk-sharing is both collective and spread more evenly among various stakeholders. These differences regarding the position of employers are related to the dominance of mandatory industry-wide pension funds in the Netherlands. Additionally, the 
role of unions as agents of social solidarity has remained important in the Netherlands. This is an important difference with the US, where the demise of DB plans seems to be related to the decline of unionism. Finally, in contrast to the UK and the US, the unions' concern for social solidarity is broadly supported in Dutch society, and none of the political parties has come out in favor of strengthening personal pension provision at the cost of second- (or first-) pillar pensions. These points - the shared governance of pension funds, the position of unions, and the societal support for social solidarity and collective risk-sharing — are discussed in greater detail below.

\section{The position of employers}

In Anglo-Saxon pension funds, employers contribute to the pension plans, direct the investments and bear the risks. Employers were fully responsible for correcting situations of under-funding in defined benefit plans (Laboul and Yermo 2006: 506). Thus, compared to continental European countries, Anglo-Saxon countries have generally allowed a much greater involvement of employers in the administration of pension funds, and employers have been given greater flexibility to correct under-funding (idem). New accounting rules have forced employers to reveal their risks in defined-benefit systems more clearly. As a result, shareholders are pushing for closer matching of risks and liabilities and for shifting investments and longevity risks to employees. Just after these new accounting rules were implemented, funding ratios of US and British pension plans fell sharply - to levels of 80 percent (thus much deeper than funding ratios of Dutch company funds) - which caused the pressure on defined benefits to come to a head (Munnell 2006: 375). This explains why the perfect storm accelerated the longer-term shift in the Anglo-Saxon world from DB plans to individual DC plans.

Similar to their counterparts in other continental European countries, pension funds in the Netherlands are independent financial institutions with their own governance and administrative structure separate from that of the employers (Laboul and Yermo 2006: 506). Dutch pension funds therefore argue that risk-sharing is spread more broadly in Dutch pension funds, that the funds and not employers are responsible for correcting situations of under-funding, and that the new accounting rules should consequently be applied differently for Dutch pension funds. The legal status as a separate trust gives pension funds a significant degree of operational autonomy that is not always present in the Anglo-Saxon trust model (ibid). Employers and unions are equally represented on Dutch pension fund boards. Thus, in contrast to the Anglo-Saxon definedbenefit plans, employers in continental Europe are less able to dominate and to direct pension fund management and policy, and therefore must compromise more with unions. The other side of the coin, however, is that they also are not regarded as exclusively responsible for correcting situations related to under-funding and risk-bearing. This contrast is accentuated by the dominance in the Netherlands of industry pension funds, which are absent in the Anglo-Saxon world. Individual DC elements in pension plans are virtually absent within industry pension funds, and risk-sharing is still predominantly done collectively through policy ladders (see section 2.4). 
The importance of unions as agents of social solidarity

Especially in the United States, the shift from DB plans to individual DC plans has been related to the decline of unionism. Ghilarducci (2006: 385) notes that unions operate on the principle of solidarity - a context of shared interests, responsibilities, and fellowship that helps to explain why they prefer DB plans to individualistic DC plans ${ }^{2}$. The decline in unionism, defined-benefit plans and pension funding is related to the employment shift from large hierarchic manufacturing firms and industries to the more diverse service sector (Munnell 2006: 367).

In terms of membership, Dutch unions are not particularly strong. They organize around 25 percent of employees. Also in the Netherlands union membership has declined. However, the institutional set-up of labor relations gives unions a much stronger position than their true power permits (see Crouch 1993: 289). As an example, the coverage rate of collective bargaining is very high (over 80 percent). This has to do with both the high organization rate of employers and the mandatory extension of collective contracts (see European Commission 2004: 30-31).

Also the institutional set-up of the pension system gives unions a stronger position than is merited by the unions' membership ratio. The mandatory extension of collective contracts is historically intertwined with the mandatory extension of industry pension funds, which predominantly explains the high pension coverage rate in the Netherlands. The representation of unions in pension boards gives them a strong institutional position.

Societal and political support for collective risk-sharing

The shift to individualistic DC plans in the US and the UK has a strong ideological and political dimension. In the 1980s, the conservative government of Ms. Thatcher aggressively promoted the opt-out of collective pension schemes to individual pensions (Munnell 2006: 371). In the US, personal pension provision is high on the political agenda of the Republican Bush administration. Moreover, as Wiles (2006) shows, Republican ideology is pushing DC plans through state legislatures, while the Democrats and their union supporters are attempting to block these plans for public workers.

In the Netherlands, in contrast, a shift to individual pension provision is not on the political agenda. Surveys show that most people prefer collective risk-sharing over individual DC plans with greater investor autonomy, and that there is a high degree of household confidence in the current pension scheme (Van Rooij, Kool and Prast 2005). We show in section 5.3 and in the appendix that this preference for collective risk-sharing is supported by economic analysis.

The willingness to share risk collectively and to accept its possible distributional consequences presupposes a certain degree of societal trust. Indeed, the European and World Value studies show a relatively high degree of social trust in the Netherlands (Dekker and van den Broek 2005:

\footnotetext{
${ }^{2}$ For a more elaborate discussion of the importance of social solidarity for collective pension provision, see: De Deken, Ponds $\&$ Van Riel (2006).
} 
49). Such a high level of trust is also found in the Scandinavian countries. These surveys also indicate that social trust seems to be relatively low in the US and the UK.

\section{From hybrid DB/DC pensions to collective DC plans}

\subsection{A further evolution towards collective DC}

As mentioned in section 3.2, a number of pension funds have already gone one step further than the hybrid plan by abolishing the use of the contribution rate as a risk-steering instrument. We characterize this type of plan as a collective $D C$, and expect more pensions funds to follow. The main reason for this is that the volatility in contribution rates remains relatively high in hybrid pension plans (see table 9). This will be magnified by the effect of ageing, which will severely undermine the effectiveness of the contribution rate as a steering instrument (see section 4.2).

However, as shown in figure 1, a further step towards a collective DC will lead to even more redistribution from old to young. This might be both undesirable (in view of the risk-bearing capacity of the old) and unacceptable for the old. We therefore expect this shift to a collective DC to be accompanied by a rethinking of the intergenerational contract, leading to more differentiation in risk exposure between younger and older members (compare Boeri 2006: $68 \mathrm{ff}$ ).

\subsection{Rethinking the intergenerational contract}

Pension funds in the Netherlands typically administer a uniform pension plan for heterogeneous groups of plan members. The funding process has a collective base: one asset mix, a uniform contribution rate and risk-sharing. In the coming decades, the degree of maturity of many pension funds in the Netherlands will increase. For example, within the largest pension fund ABP, the relative share of non-active members (primarily retirees) in the total liabilities will rise from less than $40 \%$ in 2004 towards $70 \%$ within 20 years. This increase will inevitably affect the asset mix. The investment policy will necessarily become more conservative in order to ensure that the indexation promise can be met to the greatest extent possible. A conservative mix will not be attractive for younger workers, as the low return on assets implies higher contributions to fund the accrual of their new liabilities. Young workers, moreover, regard a conservative asset mix for their retirement savings as far from optimal, from the optimal lifecycle planning perspective (see Appendix).

We foresee that pension funds will evolve in their ability to differentiate more in risk exposure between younger and older members. This risk differentiation should particularly be oriented toward realizing more certainty for the elderly regarding the indexation of their benefits and allowing the younger members to have more risk exposure so that they have the prospect of higher returns. A challenging question in such a redesign of the pension plan is whether or not it 
is possible to combine risk differentiation regarding ages with a safeguarding of the benefits of collective funding and intergenerational risk-sharing.

At least two basic choices in the design of an age-dependent policy can be discerned. Both options enable risk differentiation to ages, and both are in line with the recommended risk strategy of the theory of optimal individual lifecycle planning.

\section{Age-dependent indexation policy}

One way to achieve an age-dependent risk policy is to adjust the indexation rule to ages. The current indexation rule for a typical pension plan is that accrued benefits are indexed yearly for the growth of wages in the industry. A policy ladder may be operative, so that the actual indexation rate depends on the financial position of the pension fund. This indexation rule can be adjusted easily to arrive at an age-dependent indexation policy. The indexation consists of two parts. The first is related to wage growth, as in the current setup. The second part is related to the excess return over the discount rate of real liabilities. For a wage-indexed defined-benefit plan, this discount rate has to be equal to the difference between the (expected) nominal rate of interest and the (expected) wage growth.

For $x \leq 64$ years:

Indexation $=\left(\frac{\mathrm{x}-25}{40}\right) *$ wage growth $+\left(\frac{65-\mathrm{x}}{40}\right) *\left(\mathrm{R}_{\mathrm{A}}-\mathrm{d} \%\right)$

For $x>64$ years:

Indexation $=$ wage growth

where

$\mathrm{x} \quad=$ age of participant

$\mathrm{R}_{\mathrm{A}} \quad=$ return on (selected) asset mix

$\mathrm{d} \% \quad=$ discount rate indexed liabilities

With the introduction of such an indexation rule, it may also be possible to split up the asset mix in two parts: a conservative asset mix (underlying the part of the liabilities where the indexation is related to wage growth) and a more risky asset mix (underlying the liabilities of which the indexation is related to the excess return). An open question is what the impact may be of a situation of under-funding or over-funding on the overall indexation. A policy ladder may still be operative in correcting the actual indexation for the funding position.

A main advantage of this indexation rule is that an age-dependent policy of risk differentiation can be implemented, with safeguards for the institutional structure of pension-fund plans in operation, as plan members continue to build up new liabilities for each year of service. The only thing that has been changed is the nature of the indexation policy for the workers. 
"First DC, then $D B$ "

A more radical idea is to allow workers to keep their contributions in an individual DC plan. Upon retirement, the end value of the DC account is converted in indexed DB liabilities. The asset management for the $\mathrm{DC}$ accounts is carried out by professionals who aim to establish an investment strategy in line with the recommendations of individual lifecycle planning. The management of the assets relating to the DB liabilities is also a responsibility of professionals. These assets are held in an asset mix that is a good approximation of the perfect match for DB liabilities. A perfect match can be realized when workers sell wage-indexed bonds to the elderly that are equal to the value of the liabilities of the elderly. In turn, the workers get to manage the assets of the elderly. These assets are held in a risky portfolio. The net return of the leveraged position is equal to difference between the return on assets in the risky portfolio minus the costs of indexation, which is related to the growth rate of wages. This net return must be distributed among the workers according to some agreed-upon rule. This return supplements the increase in accrued liabilities due to the regular wage growth. This contract gives the elderly the prospect of indexation certainty, whereas the young may expect a higher growth rate of their liabilities.

\subsection{Collective DC versus individual DC}

As appropriate benefit adjustmetns take up a large part of pension-fund risk in the new collective schemes, one may wonder what the advantages are of keeping the collective scheme compared with an individual DC scheme. We use the ALM analysis presented in section 3 to compare the collective and individual approaches.

Since we strive for a level playing field in the comparison, we compare the individual DC plan with a collective DC plan, as both schemes have a fixed contribution rate. It is assumed that both plans have the same ambition level of a pension income of $80 \%$ of average wage for a working period of 40 years. The funding process is also comparable. Both plans have a fixed contribution rate of $18 \%$. The asset mix in both plans consists of $50 \%$ bonds and $50 \%$ stocks. The collective DC plan has an initial real funding ratio of $100 \%^{3}$.

We evaluate for a 20-year horizon. The output of the collective plan is the same as that reported in the preceding section. At the end of the 20 years, the mean and median of the funding ratio of the collective DC plan are around $130 \%$ due to an average excess return of more than $2 \%$. The counterpart of the funding ratio of the DB plan for a DC plan is the ratio of accumulated wealth over the required wealth to realize the target of $80 \%$ average wage income. We report for this ratio the mean, median, and the probability of under-funding.

Table 10 reports for the collective plan some key results of the indexation ratio. For the individual DC plan we used a constructed indexation ratio. We translated the accumulated wealth at the end of the 20-year period in terms of the actual indexation reserve vis-à-vis the required

3 Note that this differs from the simulations in section 6 where we start with a real funding ratio of $85 \%$, i.e. a situation of under-funding. 
indexation reserve to realize the target of $80 \%$ average wage income. The table shows that in both plans the mean and median of the indexation ratio come close to the aimed level of $100 \%$, although the DC plan leads to considerably higher volatility in the indexation ratio compared to the hybrid plan. The individual DC plan has both a high upside risk and a high downside risk, as can be seen from the reported results on probability of cumulative indexation ratio.

Table 10. ALM results for collective DC plan and individual DC plan 2006-2025

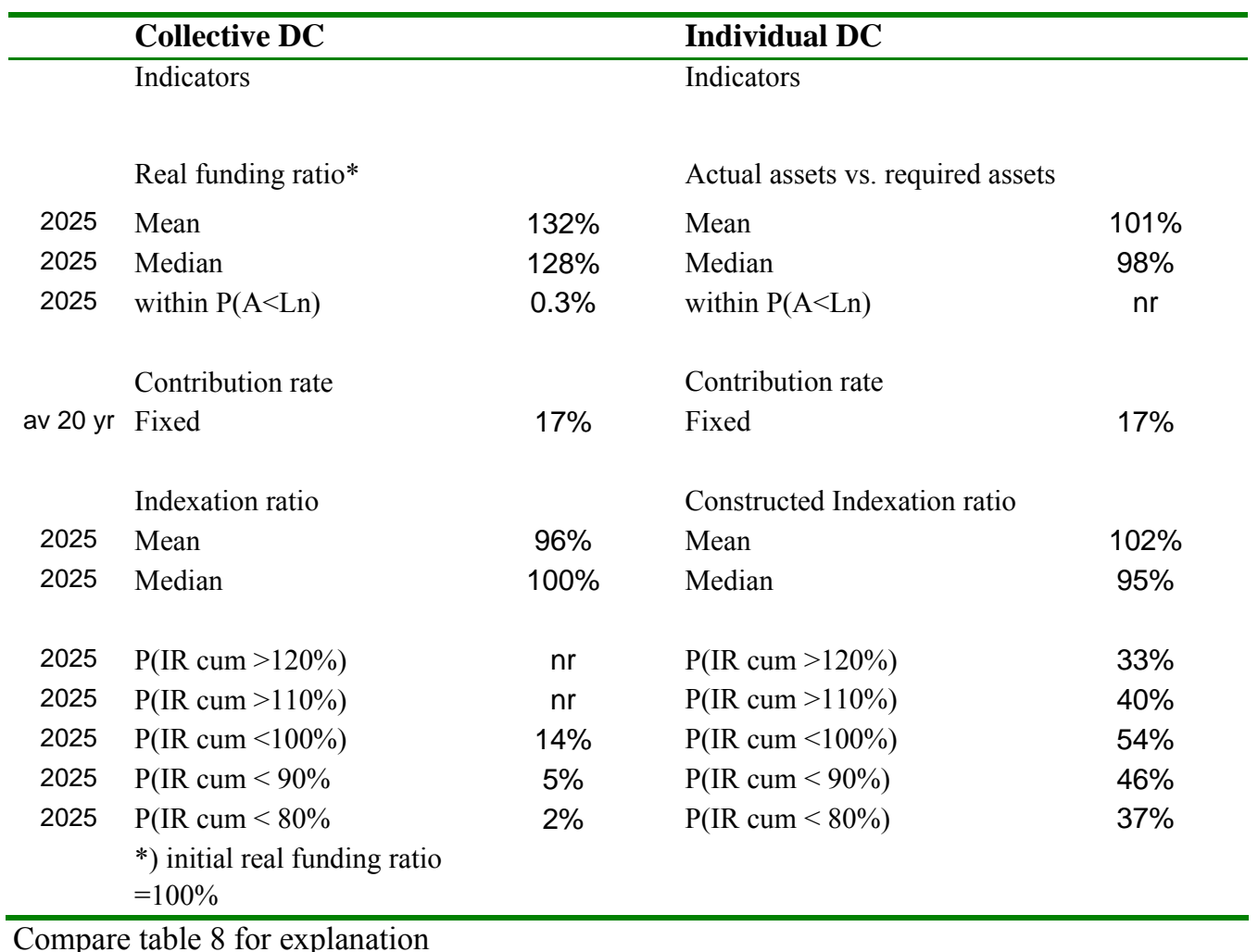

Compare table 8 for explanation

The risk exposure in DC plans in real life will be even larger than the results reported in table 10. First of all, we distinguish only one type of financial market risk: the uncertainty regarding the real return on DC savings (i.e. the gross return on investments minus wage growth). Workers who want to convert the DC wealth into annuities at the end of their working period have to face additional risks. This concerns both the uncertainty regarding the prevailing market rate of interest at the moment of conversion, and the fact that workers who have bought nominal annuities are exposed to inflation risk

We calculated what the costs would have been to buy a nominal annuity of 1 euro for the period of 1956-2006, given the nominal rate of interest prevailing in those years for a 65 -year-old man. We applied the same mortality table over the entire period 1949 to 2005 . Figure 2 reports the results. The costs of the one-euro nominal annuities varied considerably over this period. In general, the higher the rate of interest, the lower the costs are for a one-euro nominal annuity, as the insurance company can invest in higher yielding bonds. 


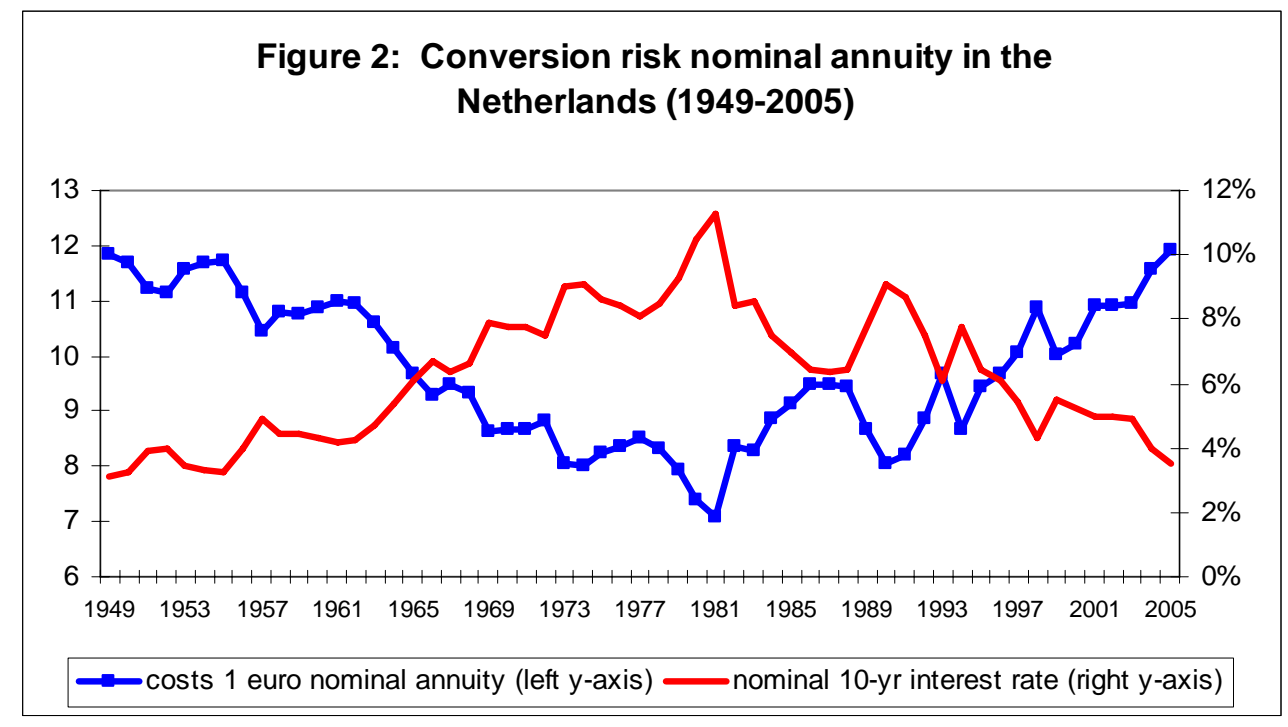

DC plans in real life are far from cost-effective. Table 11 below presents the results of a study of the central bank in the Netherlands on the operational costs of pension funds and life insurance companies. Costs related to investments are omitted. The differences in costs are enormous. The costs as a percentage of assets under management for the insurance companies are around eight times higher than for pension funds. Moreover, life insurance companies mark up the costs with a profit margin. For a typical policyholder, $2.35 \%$ of the investment return is directed to the insurance company. Pension funds need only $0.15 \%$ to back their operational costs. The remaining part of the investment returns is available for the plan members.

Table 11. Operational costs of life insurance companies and pension funds (ave. 2000-2004)

\begin{tabular}{|c|c|c|c|c|}
\hline & Pension funds & \multicolumn{3}{|c|}{ Life insurance companies } \\
\hline & Operational costs & Operational costs & Profit margin & Total \\
\hline$\%$ of contributions & 4.4 & 12.9 & 11.0 & 23.9 \\
\hline$\%$ of total assets & 0.15 & 1.27 & 1.08 & 2.35 \\
\hline
\end{tabular}

Source: Bikker and De Dreu (2006)

The impact of costs on the final pension result is huge. Let us assume that the additional costs of individual plans vis-à-vis collective plans are of the magnitude of $0.5 \%$ and $1 \%$, respectively. When the policyholder at the insurance company pays the same contribution rate (equal to $18 \%$ ) as the plan member in the pension fund, then he will end up with $11 \%(21 \%)$ less pension income compared with the pension-fund participant. The policyholder may react to the high cost structure 
by paying more contributions. The required increase in the contribution rate would be $2.5 \%(5 \%)$ yearly.

\section{Conclusion}

Mainly in reaction to the fall in funding ratios at the beginning of this century, Dutch pension funds switched from final-salary schemes to average-wage schemes, which are both classified by official statistics as DB schemes. This contrasts with the situation in the UK and the US, where the fall in pension funding ratios as a consequence of the stock market crash accelerated the switch from DB pension plans to DC pension plans. However, we have shown in this study that the typical current Dutch pension plan has to be regarded as a hybrid DB-DC plan. Since these hybrid plans make use of two steering mechanisms to control solvency risk, they are quite effective in minimizing the risk of under-funding.

The current hybrid pension plan reflects a compromise between the different stakeholders in Dutch pension funds. Pension funds in the Netherlands are independent financial institutions governed by a board on which both employers and unions are represented. In contrast, the influence of employers in the Anglo-Saxon pension funds is much greater, and they are - as sponsors of pension funds - responsible for correcting situations of under-funding. This difference in the government and regulation of pensions funds goes a long way in explaining why in the US and the UK there has been a stronger shift to individual DC schemes (where employers have shifted risks to individual employees), while in the Netherlands risk-sharing is both collective and spread more evenly among various stakeholders. These differences with respect to the position of employers are related to the dominance of mandatory sector-wide pension funds in the Netherlands. Additionally, the role of unions as agents of social solidarity has remained important in the Netherlands. Finally, we pointed out that there is much societal and political support for collective risk-sharing in the Netherlands, which reflects a high level of social trust.

We expect that the role of the employer in bearing risk will be reduced, and that the current hybrid schemes will evolve toward stand-alone multimember collective DC pension plans. This will be accompanied by more differentiation in risk exposure between younger and older members. Risk differentiation will help elderly members to obtain more certainty regarding the indexation of their benefits and younger members to have more risk exposure so that they have the prospect of higher returns.

Collective risk-sharing will thus remain an important element in Dutch pension funds. This contrasts with developments in the Anglo-Saxon world, where more risks are shifted toward the individual. In this sense, the evolution of Dutch pension schemes diverges from the developments of Anglo-Saxon pension funds. Finally, we argued that collective risk-sharing has some important advantages over individual risk-sharing. 


\section{Bibliography}

Bikker J. and J. de Dreu (2006), Uitvoeringskosten van pensioenverstrekkers, in: Steenbeek O \& F. van der Lecq: (eds): 'Kosten en baten van collectieve pensioenen', Kluwer, December.

Bodie Z., R.C. Merton and W.F. Samuelson (1992), Labor supply flexibility and portfolio choice in a life cycle model, in: Journal of Economic Dynamics and Control, pp. 427-449.

Boender C.G.E., A.L. Bovenberg, S. van Hoogdalem \& T.E. Nijman (2006), Optimale risicodeling in individuele en collectieve pensioencontracten, in: Steenbeek O \& F. van der Lecq: (eds): 'Kosten en baten van collectieve pensioenen, Kluwer, December.

Boeri, T., A.L. Bovenberg, B. Coeuré and A. Roberts (2006), Dealing with the new giants: Rethinking the role of pension funds, CEPR Geneva Reports on the World Economy.

Constantinides G.M., J.B. Donaldson and R. Mehra (2005), Junior must pay: Pricing the implicit put in privatizing social security, in: Annals of Finance, vol. 1(1), pp 1-34.

Crouch, C. (1993), Industrial Relations and European State Traditions, Oxford: Oxford University Press.

Cui J., F. De Jong and E.H.M. Ponds (2006), Intergenerational risk sharing in collective pension schemes, working paper Netspar, Tilburg University.

De Deken, J.J., E.H.M. Ponds and B. van Riel (2006), Social solidarity, in: G. L. Clark, A.H. Munnell and J.M. Orszag (eds.), Oxford Handbook of Pensions and Retirement Income, Oxford: Oxford University Press.

Dekker, P. and A. van den Broek (2005), Involvement in voluntary associations in North America and Western Europe: Trends and correlates 1981-2000, Journal of Civil Society, vol. 1(1) pp. 45-59.

European Commission (2004), Industrial relations in Europe 2004, Luxemburg.

Ghilarducci, T. (2006), Organised labor and pensions, in: G.L. Clark, A.H. Munnell and J.M. Orszag (eds.), Oxford Handbook of Pensions and Retirement Income, Oxford: Oxford University Press.

Gollier, C. (2005), Intergenerational risk sharing and risk taking of a pension fund, working paper, Toulouse.

Gordon, R.H., and H.R. Varian (1988), Intergenerational risk sharing, Journal of Public Economics, vol. 14, pp. 1-29.

Hoevenaars, R.M. and E.H.M. Ponds (2006), Valuation of intergenerational transfers in funded collective pension schemes, Netspar working paper, 2006-D019.

Kakes, J. (2006), Financial behaviour of Dutch pension funds: A disaggregated approach, DNB Working paper no. 108. 
Kortleve, N.E., T.E. Nijman and E.H.M. Ponds (2006) (eds.), Fair Value and Pension Fund Management, Elsevier Science.

Munnell, A.H. (2006), Employer-Sponsored Plans: The shift from defined benefit to defined contribution, in: G.L. Clark, A.H. Munnell and J.M. Orszag (eds.), Oxford Handbook of Pensions and Retirement Income, Oxford: Oxford University Press.

Laboul, A. and J. Yermo (2006), Regulatory principles and regulation, in: G.L. Clark, A.H. Munnell and J.M. Orszag (eds.), Oxford Handbook of Pensions and Retirement Income, Oxford: Oxford University Press.

OECD (2004), Economic Survey Netherlands, vol. 2004/9/. Paris.

OECD (2006), Pension markets in focus, October 2006, Issue 3, Paris.

Van Riel, B., A. Hemerijck and J. Visser (2003), Is there a Dutch way to pension reform?, in: G.L. Clark and N. Whiteside (eds.). Pension Security in the 21st Century, Oxford: Oxford University Press.

Van Rooij, M., C. Kool and H. Prast (2004), Risk-return preferences in the pension domain: Are people able to choose?, Journal of Public Economics.

Shiller, R.J. (1999), 'Social security and institutions for intergenerational, intragenerational and international risk sharing', Carnegie-Rochester Conference Series on Public Policy, vol. 50, pp. 165-204.

Smetters K. (2003): Controlling the cost of minimum benefit guarantees in public pension conversions, in: NBER Working Papers 8732.

Teulings C.N. \& C. de Vries (2006): Generational accounting, solidarity, and pension losses, in: De Economist 154 nr. 1, (March) pp. 63-83.

Van Vuren, A. (2003): Financiële consequenties PVK-regels, CPB Memorandum.

Wiles, G. (2006), Why are there any public defined contribution plans? Mimeo. 


\section{APPENDIX}

\section{Rationale for funded multi-member plans with intergenerational risk-sharing}

\section{A.1 Introduction}

The pension crisis has involved a lively debate - particularly among academic economists — on the merits and disadvantages of intergenerational risk-sharing within funded multi-member plans. Is it still worthwhile to structure pension-plan provision on the basis of intergenerational risksharing? The broadly shared conclusion from this debate is that although intergenerational risksharing may indeed lead to welfare improvement for the members, the plan design is of crucial importance (Teulings \& de Vries 2006; Cui et al. 2006; Boender et al. 2006). This section gives an overview of the shared insights as a result of this discussion.

\section{A.2 Optimal lifecycle financial planning}

The literature on optimal lifecycle planning points out that the optimal investments in risky assets over the lifecycle should be structured as follows:

$$
f(x)=\frac{\mu-r}{\theta \sigma^{2}} \frac{H C_{x}+F_{x}}{F C_{x}}
$$

where:

$$
\begin{array}{ll}
\mathrm{f}(\mathrm{x}) & =\text { fraction of financial capital in stocks at age } \mathrm{x} \\
\mu & =\text { expected rate of return stocks } \\
\mathrm{r} & =\text { risk-free rate } \\
\theta & =\text { risk aversion } \\
\sigma^{2} & =\text { riskiness of stocks (variance) } \\
\mathrm{HC}_{\mathrm{x}} & =\text { human capital at age } \mathrm{x} \\
\mathrm{FC}_{\mathrm{x}} & =\text { financial capital at age } \mathrm{x}
\end{array}
$$

The first part in the right-hand side of expression (1) is the standard result from the literature on dynamic asset allocation over time. Under some conditions, which are quite restrictive of nature but broadly accepted in theoretical analysis, this term says that the individual should maintain a constant part of financial wealth in risky assets over his lifecycle, regardless of the size of wealth and age. The share in risky assets is increasing in the risk premium $\mu-r$, defined as the difference between the expected return on risky assets $\mu$ and the risk-free rate $r$, and decreasing in the degree of riskiness of the risky assets $\sigma^{2}$ and the coefficient of relative risk aversion $\theta$. The standard result of the first term is derived under the following conditions: 
[1] The risk attitude of the individual is characterized by constant relative risk aversion, which means that the individual maintains the same percentage exposure to risky assets regardless of the changes in wealth.

[2] Investment returns follow a random walk (returns are independent and identically distributed); there is no mean reversion.

[3] Since the individual has no other income than investment income, personal wealth is financial wealth.

Personal wealth of an individual consists not only of financial capital but also of human capital. Bodie et al. (1992) show that the asset allocation rule has to be augmented with the second part in expression (1). The term HC reflects the present value of remaining human capital, which approximately equals the stream of wages to be received over the rest of the working period. The term FC is the value of financial assets at the moment of evaluation. The sum of $\mathrm{HC}$ and $\mathrm{FC}$ is available for consumption over the remaining lifetime. As figure A.1 displays, personal wealth is at a maximum when an individual enters the labor market. Personal wealth gradually declines over the lifetime, as wealth is transmitted in yearly consumption. Since at retirement age (say 65) all human capital is depleted, consumption during retirement must come from financial capital.

\section{Figure A1: Personal wealth over the lifecycle and its components}

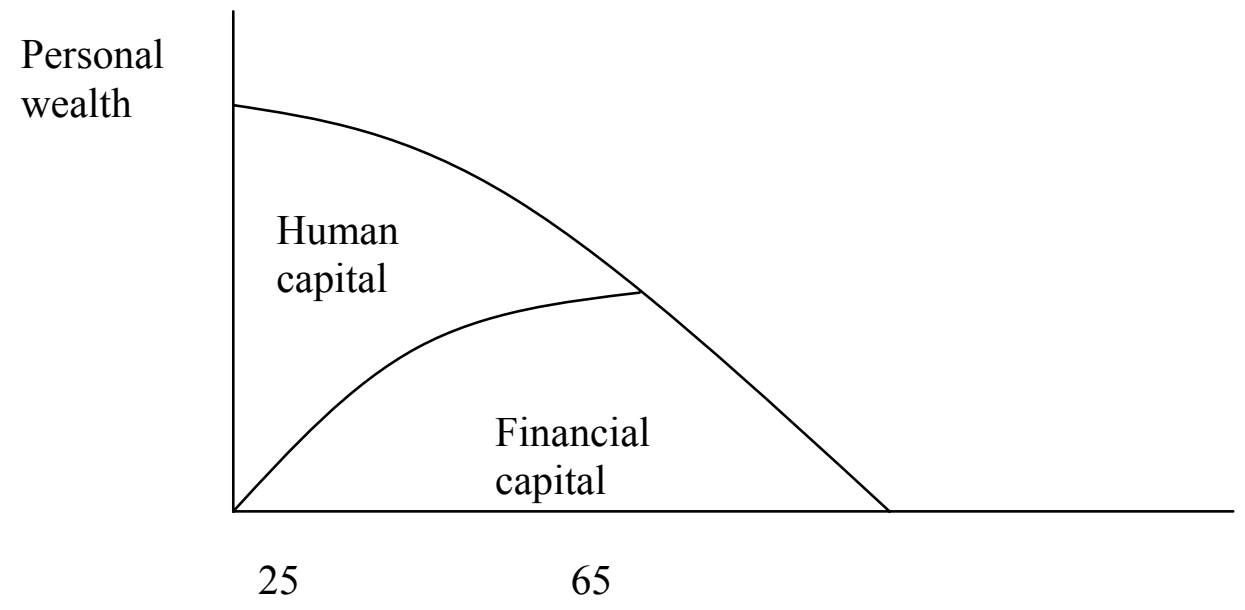

Expression (1) actually states that young individuals should invest a large part of their personal wealth in risky assets, and that they should subsequently diminish gradually the relative share of risky assets in personal wealth as they grow older. This strategy improves the return-risk tradeoff over the lifecycle as it employs risk diversification possibilities between human capital and financial capital. Essentially, it is based on the exploitation of the correlation between the return on human capital (wage growth) and financial capital (stock market return). The optimal rule suggests that workers in their youth should borrow in bonds and use the proceeds to invest in stocks. Figure A.2 displays the relative share in stocks as a percent of financial capital. 


\section{Figure A2: investment in stocks as a percent of financial capital}

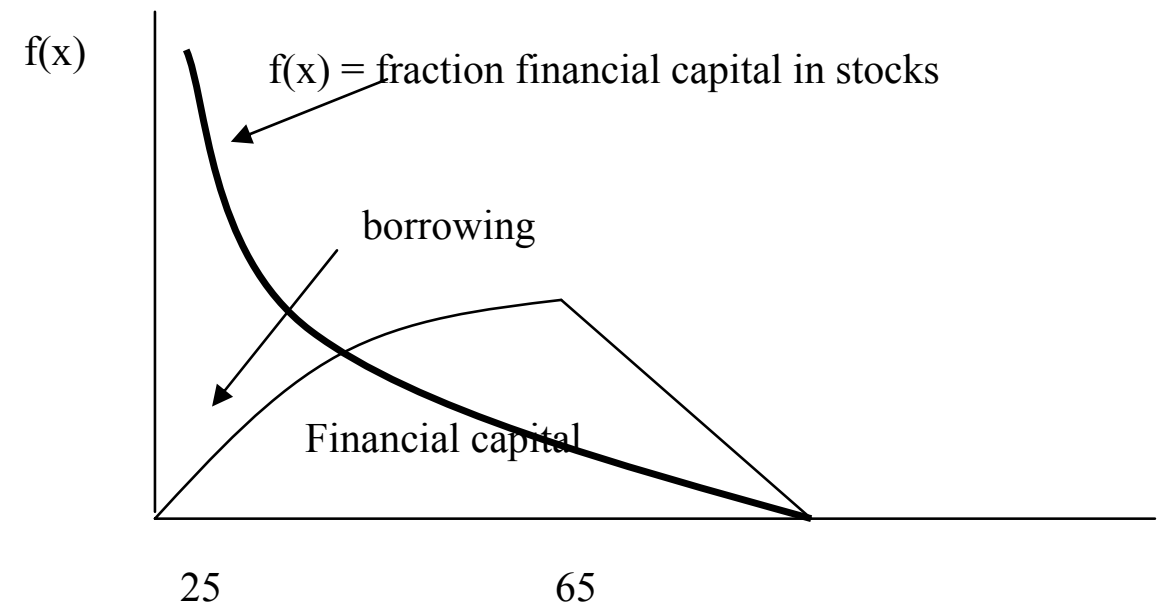

In real life, individuals find it difficult to realize optimal asset allocation over time. Three main reasons can be mentioned:

\section{[1] Borrowing constraints}

Expression (1) implies that young individuals should exchange their human capital in financial capital in order to eliminate exclusive exposure to human capital risk and to replace it by a diversified portfolio consisting of human and financial capital. A high share of their wealth in risky assets can be realized when young individuals have to borrow and invest the borrowed sum in risky assets. Young individuals, however, face borrowing constraints. Although they have a large value of human capital, they cannot borrow with their future wage income as collateral, due to adverse selection and moral hazard. Young individuals thus cannot realize the optimal relative share in risky assets.

\section{[2] Missing market for trade between current and future generations}

Over their working period, workers build up financial capital from savings out of their wage income. The literature on intergenerational risk-sharing (Shiller 1999; Gordon \& Varian 1988; Gollier 2006) clarifies that the tradeoff between return and risk offered by the financial market could be improved considerably if the current generations would be able to trade with future generations (not yet born or in school). Macroeconomic shocks could then be distributed over time and among more individuals, which diminishes individual exposure to shocks. Capital markets cannot offer financial assets that enable intergenerational risk-sharing, as the current generation cannot commit the future generation to the intergenerational contract.

The argument applies particularly to those shocks that hit all members of a generation in the same way, like inflation shocks and productivity growth shocks. One natural way to organize intergenerational risk-sharing is to allow young and future generations to sell index-bond linked to inflation or productivity growth to the elderly. The young and future generations pay the elderly when inflation or productivity growth is higher than expected, and they receive from the 
elderly when inflation and productivity growth is lower than expected. A second way to organize intergenerational risk-sharing is that young generations provide guarantees to the elderly regarding the minimum return on their retirement savings. Effectively, this comes down to the situation that the young generation writes a put option. This idea is discussed by Smetters (2003) and Constantinides et al. (2005) in relation to the debate in the US to reform the social security pay-as-you-go scheme into a privatized funded DC scheme. A third way to organize intergenerational risk-sharing is to facilitate the sharing of risks between young and old members in collective funded pension plans within the institutional setting of a pension fund. This is discussed below in section A.3.

\section{[3] Sub-optimal individual decision-making}

Optimal decision-making over the lifecycle requires that individuals constantly reconsider their asset allocation and planned consumption path in relation to changes in their realized wealth position and their expectations for the future development of personal wealth. The now widespread insights of behavioral finance clarify that most (if not all) individuals fail to realize the optimal policy due to a lack of expertise, myopic behavior, hyperbolic discounting and so on. In real life, furthermore, individuals face high transaction costs in trading on financial markets or in making use of financial intermediation.

\section{A.3 Collective plans with intergenerational risk-sharing}

Funded multi-member plans with intergenerational risk-sharing and mandatory participation have the potential to overcome the problems sketched above with regard to realizing optimal lifecycle asset allocation. As a point of reference we evaluate an average-wage plan, where indexation is conditional on the financial position of the pension fund ruled by a policy ladder. The contribution rate may be either flexible or fixed.

A shock in the stock market affects the financial wealth position of individuals. According to optimal lifecycle planning, individuals must react by adjusting their consumption path for the remaining part of their lifetime according to the change in the financial wealth position. The stock market shock also impacts pension-fund wealth. The rules of the policy ladder prescribe whether and to what extent the change in pension fund wealth is transmitted to adjustments in the indexation and contribution rates. The weaker the relationship, the more risk is borne by future generations. The broad risk-bearing capacity of the plan explains why the impact of a shock on the individual consumption path is smaller compared to the consumption adjustment in the optimal individual plan, as losses and gains can be distributed among current and future plan members. The young and future members increase their risk exposure, moreover, as they take over a part of the funding risks related to the accrued rights of the elderly. Furthermore, professional decision-making and asset management on behalf of the members prevents individual failures in lifecycle financial planning. Finally, a collective plan appears to be highly cost-effective. 


\section{RECENT WORKING PAPERS FROM THE}

\section{CENTER FOR RETIREMENT RESEARCH AT BOSTON COLLEGE}

Social Security Spouse and Survivor Benefits for the Modern Family

Melissa M. Favreault and C. Eugene Steuerle, February 2007

How Economic Security Changes During Retirement

Barbara Butrica, February 2007

International Investment for Retirement Savers: Historical Evidence on Risk and Returns

Gary Burtless, February 2007

Job Changes at Older Ages: Effects on Wages, Benefits, and other Job Attributes Richard W. Johnson and Janette Kawachi, February 2007

Cross-National Comparison of Income and Wealth Status in Retirement: First Results from the Luxembourg Wealth Study (LWS)

Eva Sierminska, Andrea Brandolini and Timothy M. Smeeding, February 2007

Saving and Demographic Change: The Global Dimension

Barry Bosworth and Gabriel Chodorow-Reich, February 2007

The Repeal of the Retirement Earnings Test and the Labor Supply of Older Men Gary V. Engelhardt and Anil Kumar, February 2007

Persistence in Labor Supply and the Response to the Social Security Earnings Test Leora Friedberg and Anthony Webb, December 2006

Annuitized Wealth and Consumption at Older Ages

Barbara A. Butrica and Gordon B.T. Mermin, December 2006

Risk and Reward of International Investing for U.S. Retirement Savers: Historical Evidence

Gary Burtless, December 2006

State Age Protection Laws and the Age Discrimination in Employment Act Joanna Lahey, November 2006

All working papers are available on the Center for Retirement Research website (http://www.bc.edu/crr) and can be requested by e-mail (crr@bc.edu) or phone (617-552-1762). 